J. Clin. Chem. Clin. Biochem.

Vol. 24, 1986, pp. 399-403

(C) 1986 Walter de Gruyter \& Co.

Berlin - New York

\title{
Automatic Bioluminescent Glucose Determination Using Commercially Available Reagent Kits Coupled to the Bacterial NAD(P)H-Linked Luciferase System
}

\author{
By E. Wieland, E. Wilder-Smith and H. Kather \\ Klinisches Institut für Herzinfarktforschung an der Medizinischen Universitätsklinik Heidelberg, Heidelberg
}

(Received June 4, 1985/February 3, 1986)

Summary: A sensitive and specific automatic bioluminescent method is described for glucose determination in serum samples using commercially available reagent-kits. The Boehringer Gluco-quant kit, originally designed for spectrophotometric measurement, was successfully coupled to the bacterial luciferase NAD(P)Hlinked system. The method's validity was proven by comparison with a spectrophotometric method. Correlation was excellent $(r=0.98, n=50)$. Precision attained by 30 assays was good (CV $1.19 \%)$. The assay was verified by determining the glucose concentrations of more than 1000 serum samples.

Using a microcomputer-controlled automatic luminescence analyser (Berthold LB $950 \mathrm{~T}$ ) and reagent kits for luminometry (Boehringer Mannheim, LKB Wallac, Lumac/3M), the complete assay can be performed fully automatically with commercially available reagent kits.

More than 200 samples can be assayed by one individual per day. The bioluminescence method is at least 100 times more sensitive than spectrophotometric measurements. Other reagent kits tested (Behring, Merck, Sigma) are also suitable for coupling to the $\mathrm{NAD}(\mathrm{P}) \mathrm{H}$-linked luciferase system.

Automatische bioluminometrische Glucosebestimmung: Kopplung käuflicher Fertigreagenzien an das System der bakteriellen $N A D(P) H$-abhängigen Luciferase

Zusammenfassung: Es wird eine sehr empfindliche und spezifische automatische Biolumineszenzmethode zur Glucosebestimmung in Serumproben beschrieben. Die Methode basiert auf der Koppelung käuflicher Fertigreagenzien an das System der bakteriellen NAD(P)H-abhängigen Luciferase. Der Boehringer Glucoquant Testkit für die photometrische Glucosebestimmung in Serumproben wurde erfolgreich mit dem Luciferasesystem verbunden. Dadurch erhöhte sich die Empfindlichkeit des Tests ungefähr 100-fach. Die Korrelation zwischen Photometrie und Lumineszenz war gut $(r=0,98, n=50)$, die aus 30 Bestimmungen einer Probe ermittelte Präzision mit eịem Variationskoeffizienten von 1,19\% ausgezeichnet.

In Verbindung mit einem mikrocomputergesteuerten Lumineszenzgerät (Berthold LB $950 \mathrm{~T}$ ) läßt sich die Bestimmung vollautomatisch durchführen. Dadurch können von einer Person 200 Proben an einem Arbeitstag analysiert werden.

Wenn auch noch das System der bakteriellen Luciferase in Form von Fertigreagenzien verwendet wird (z. B. Boehringer, LKB Wallace, Lumac/3M), beruht der gesamte Test auf käuflichen Testkombinationen. Fertigtestkombinationen zur Glucosebestimmung anderer Hersteller (Behring, Merck, Sigma) ließen sich ebenso unproblematisch zur bioluminometrischen Messung verwenden.

Mit dem Gluco-quant Kit wurde bereits in mehr als 1000 Serumproben $(10 \mu l)$ die Glucosekonzentration bestimmt. 


\section{Introduction}

Luminescent assays are sensitive and specific. They are among the few methods with potential detection limits similar to those of radiochemical analysis. The bacterial NAD(P)H-linked luciferase system has long been regarded as an important potential replacement for conventional spectrophotometric indicator reactions in assays for substrates of dehydrogenases. Somewhat surprisingly bacterial luciferase has not yet found the wide application that might be expected from its advantages, e. g. excellent sensivity, accuracy, precision, speed and convenience. A factor hampering the exploitation of the bacterial luciferase system was that only crude preparations of varying composition were commercially available until recently. Thus it was difficult to control the reaction and to predict or explain analytical differences. During the past few years purified enzymes have become available. Problems with the keeping properties of reagents, and with the techniques needed for measuring the kinetics of rapid light production have been resolved, or are at least considerably less severe than some years ago. Because of these improvements it should now be possible to couple reagent kits based on the enzymatic production of NADH or NADPH to the bacteriallinked luciferase system. This concept was tested with four commercially available reagent kits for glucose determination, originally designed for spectrophotometric measurements (Behring, Testomar; Boehringer Mannheim, Gluco-quant; Merck, Merckotest; Sigma, Glucose); all four kits were found to be suitable.

We present a fully automatic luminescence assay using the Boehringer Mannheim Gluco-quant kit and a microcomputer-controlled luminescence analyser (Berthold LB $950 \mathrm{~T}$ ), which is at least 100 times more sensitive than the conventional method. Luminescent determination of glucose is particularly useful for analysis of neonatal blood, cerebrospinal fluid and other biological samples, which can only be obtained in small amounts. Furthermore, metabolic studies during physical exercise, using samples from a finger prick or ear-lobe puncture, are now possible. In addition, the method's high sensivity offers particular advantages for metabolic studies in single cells and various tissues.

\section{Materials and Methods}

Chemicals

All luminescence enzymes and coenzymes were obtained from Boehringer Mannheim, West Germany. Tetradecanal and raffinose were from EGA Chemie, Steinheim, West Germany and from Sigma Chemicals, München, West Germany respectively.

\section{Reagent kits}

The reagent kits for glucose measurements were from Boehringer Mannheim West Germany (Gluco-quant glucose, No. 263 826), Behring Werke Marburg, West Germany (Testomar Glucose, No. OSKK 20), Merck Diagnostica, Darmstadt, West Germany (Merckotest Glucose) and Sigma Diagnostics, St. Louis, USA (Sigma Glucose, No. 16-20).

The Behring, Boehringer and Sigma kits are based on the hexokinase/glucose-6-phosphate dehydrogenase reaction and are coupled to NADPH (Behring, Boehringer) or NADHformation (Sigma) respectively. The Merck kit is based on the glucose dehydrogenase reaction and NADH formation. Control sera were from Behring Werke ("Kontrollogen $L$ and LP"; glucose assigned values $6 \mathrm{mmol} / 1$ and $13.3 \mathrm{mmol} / \mathrm{l}$ ) and from Boehringer (precimat glucose standard $5.55 \mathrm{mmol} / \mathrm{l}$ ).

\section{Collection of blood}

Samples were obtained by vein, finger-prick or ear-lobe puncture. Samples $(10 \mu \mathrm{l})$ of serum or plașma were diluted $100-150$ times with deionized water.

\section{Bioluminescent assay}

\section{Assay cocktail}

Luciferase (1.5 U/1) and N.AD(P)H : FMN oxidoreductase (1.7 $\mathrm{kU} / \mathrm{l})$ were dissolved in a potassium phosphate buffer $(0.2$ $\mathrm{mol} / \mathrm{l}$ ) containing $0.4 \mathrm{mmol} / 1$ dithiothreitol and $67 \mathrm{mmol} / 1 \mathrm{raffi}-$ nose. Tetradecanal $(4.7 \mathrm{mmol} / \mathrm{l})$ was dissolved in a solution containing $50 \mathrm{~g} / \mathrm{l}$ bovine serum albumin, $\mathrm{pH} 7.0$ at $50^{\circ} \mathrm{C}$. Solutions were divided into portions and stored at $-20^{\circ} \mathrm{C}$. Flavin mononucleotide $(\mathrm{FMN})(0.11 \mathrm{mmol} / \mathrm{l})$ was dissolved in 0.2 mol/1 potassium phosphate $(2 \mathrm{nmol} / \mathrm{l}, \mathrm{pH} 7.0)$ and kept cool in a dark bottle. $100 \mathrm{ml}$ of the assay cocktail consisted of:

$50 \mathrm{ml}$ potassium phosphate buffer containing dithiothreitol and raffinose, $10 \mathrm{ml}$ tetradecanal solution, $1 \mathrm{ml} F M N-, 1 \mathrm{ml}$ luciferase-, $0.9 \mathrm{ml}(\mathrm{NAD}(\mathrm{P}) \mathrm{H}: \mathrm{FMN}$ oxidoreductase solution and $32 \mathrm{ml}$ deionized water. The final concentrations were $0.5 \mathrm{nmol} / 1$ tetradecanal, $1.1 \mu \mathrm{mol} / \mathrm{l} \mathrm{FMN}, 15 \mathrm{mU} / \mathrm{l}$ luciferase and $15.3 \mathrm{U} / \mathrm{l}$ NAD(P)H : FMN oxidoreductase.

The assay cocktail was prepared on a daily basis and kept cold on ice or in the refrigerator. Alternatively, commercially available bacterial luciferase reagent kits could be used. (Boehringer Mannheim, LKB Wallac, Lumac/3 M).

\section{Preincubation (glucose conversion)}

The components of each kit were dissolved according to the instructions for spectrophotometric measurements. The separate solutions of each kit were mixed together to form the incubation mixture recommended by the suppliers. $20 \mu \mathrm{l}$ of the diluted serum samples $(1: 100-150)$ were pipetted into a cuvette and placed into an automatically moved chain. Enzymatic glucose conversion was initiated by automatic injection of $80 \mu \mathrm{l}$ of the reconstituted reagent kit (Injector Pos. 3). Samples passed through a temperature controlled incubation chamber $\left(25^{\circ} \mathrm{C}\right)$ during the subsequent 5 minutes.

\section{Measurements}

Cuvettes containing $100 \mu \mathrm{l}$ sample $(20 \mu \mathrm{l}$ diluted serum sample and $80 \mu \mathrm{l}$ incubation mixture) were automatically moved into the measuring position. Initiation of the light-producing reaction was triggered by automatic injection of $0.25 \mathrm{ml}$ of assay cocktail (Injector Pos. 1). Measurements were made during the next $15 \mathrm{~s}$, at $25^{\circ} \mathrm{C}$. Stable reaction kinetics are obtained be- 
tween the $6^{\text {th }}-15^{\text {th }} \mathrm{s}$, thus allowing reliable integration to be conducted during that period. Counts integrated between the $14^{\text {th }}$ and $15^{\text {th }} \mathrm{s}$ were taken is the measure of the NAD(P)H concentration.

Glucose concentrations of samples were calculated using an external calibration curve. For computer calculation a programme will be developed by the Firm of Berthold, Wildbad, West Germany.

\section{Spectrophotometric assay}

All spectrophotometric measurements were performed according to the manufacturer's instructions. NAD(P)H determination was accomplished using a computer-controlled Beckmann DU 8 spectrophotometer.

\section{Results}

With the Gluco-quant reagents, conversion of glucose to NADPH was completed in $60 \mathrm{~s}$, using a standard solution $(100 \mu \mathrm{mol} / \mathrm{l})$ with diluted serum samples (1:100) (fig. 1). Other tested kits (Behring, Merck, Sigma) showed similar conversion times. The NAD(P)H formed was stable for at least $60 \mathrm{~min}$. Figure 2 shows a standard curve for glucose. Light production was linearly related to glucose concentrations up to $100 \mu \mathrm{mol} / \mathrm{l}$. The Behring and Merck kit had the same linear range $(2-100 \mu \mathrm{mol} / \mathrm{l})$. The Sigma kit, however, showed a less favorable range of 4-30 $\mu \mathrm{mol} / \mathrm{l}$ of glucose. Addition of $20 \mu \mathrm{l}$ fluoride to native serum samples did not interfere with the bioluminescent assay. To prove this we added "fluoride/EDTA for glucolysis inhibition" (Behring Werke) to "Kontrollogen L" as well as to serum samples and determined the glucose concentrations. Both serum samples and Kontrollogen, with and without fluoride, showed only minor fluctuations of measured glucose concentrations within given confidence limits (With fluoride: serum $5.2 \mathrm{mmol} / \mathrm{l}$, Kontrollogen L 6.0 $\mathrm{mmol} / \mathrm{l}$. Without fluoride: șerum $4.9 \mathrm{mmol} / \mathrm{l}$, Kontrollogen L $6.1 \mathrm{mmol} / 1$; duplicate determinations).

Slight haemolysis or lipaemia caused no detectable error in the estimation of glucose concentrations by the luminescent method.

\section{Validation of the bioluminescent method}

Verification was achieved by comparison of results with those obtained for the same serum samples using the spectrophotometric method (Boehringer kit). The data obtained from 50 samples showed a linear regression of $r=0.98, y=0.96 x+0.17$ (fig. 3). The accuracy of each series of measurements was shown by the estimation of the glucose content in control serum for clinical chemistry (Kontrollogen L and LP, Behring Werke); values obtained were always within

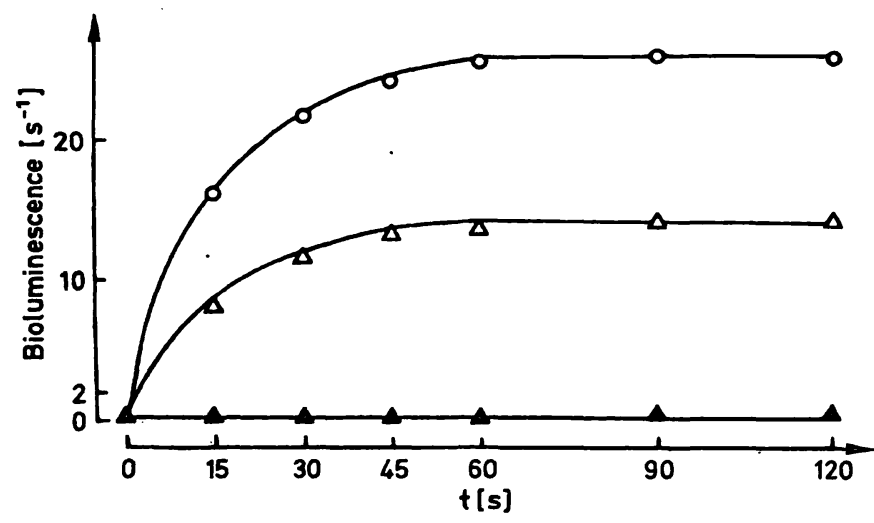

Fig. 1. Time course of glucose conversion using the Glucoquant reagents.

- Standard solution $(100 \mu \mathrm{mol} / \mathrm{l})$

$\Delta$ Serum sample (100-fold diluted)

$\Delta$ blank

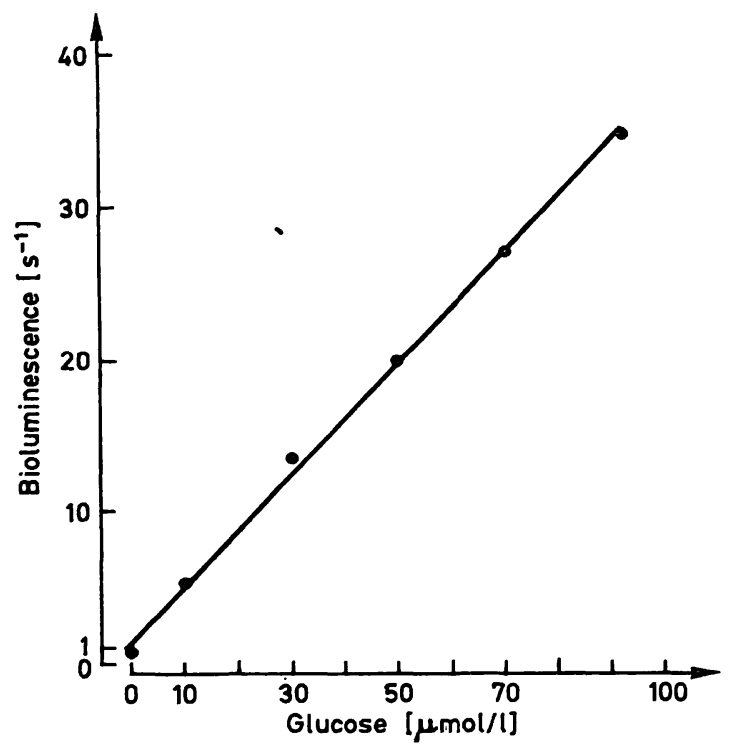

Fig. 2. Standard curve for glucose using the Gluco-quant-kit.

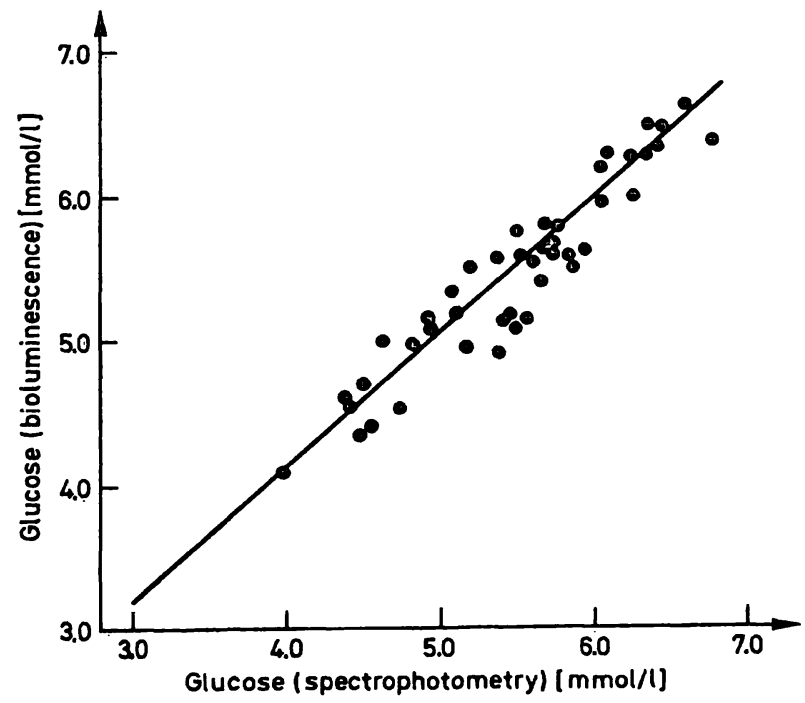

Fig. 3. Comparison between spectrophotometry and bioluminescence using the Gluco-quant reagents.

For bioluminescence, serum samples were diluted 150 times.

$y=0.96 x+0.17 ; r=0.98 ; r=50$ 
the confidence range. Duplicate measurements are not necessary. The interassay variation derived from 30 assays showed an excellent CV of $1.19 \%$ (Precimat glucose standard solution Boehringer $5.55 \mathrm{mmol} / \mathrm{l}$, $\overline{\mathrm{x}} 5.52, \mathrm{SD} 0.07, \mathrm{~S} \overline{\mathrm{x}} 0.01$ ). After 2 hours, the luciferase mixture should be checked for possible changes in activity, using glucose calibration concentrations.

To test the stoichiometry of NADPH formation, light production (counts $\times 10^{3} / \mathrm{s}$ ) of a NADPH calibration curve and a glucose calibration curve was compared (fig. 4). The experiment showed the NADPH calibration curve to be identical to that of the glucose calibration curve.

The recovery of one glucose concentration (25 $\mu \mathrm{mol} / \mathrm{l})$ added to 5 appropriately diluted serum samples averaged $97 \%$.

For regression data obtained from the other tested kits, see table 1.

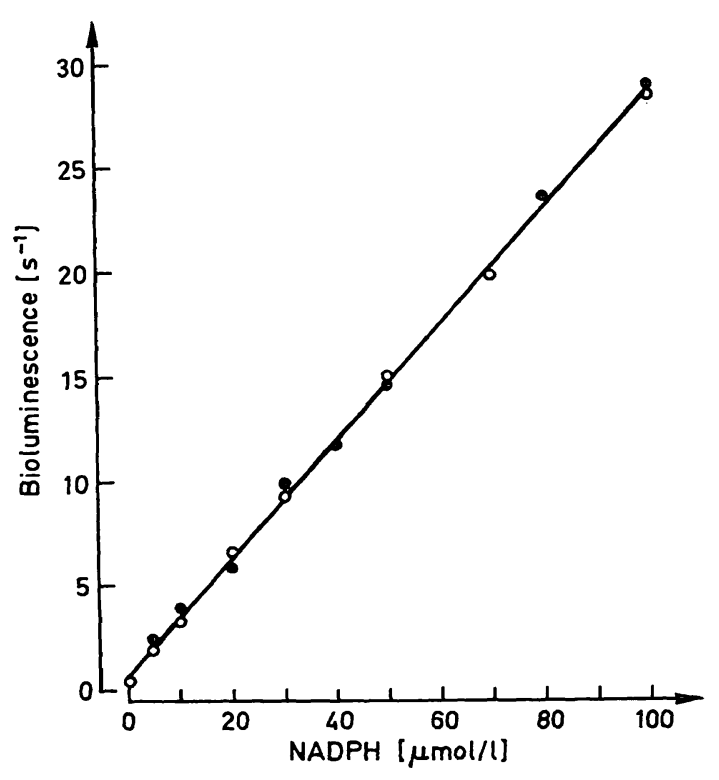

Fig. 4. Stoichiometry of NADPH-formation by the Glucoquant-kit.

Comparison of a glucose calibration curve (0) and a

Tab. 1. Regression data comparing spectrophotometry and bioluminescent application of the reagent kits tested. Experimental procedure as under Materials and Methods.

\begin{tabular}{lllll}
\hline Test Kit & $\mathrm{r}$ & $\mathrm{y}$ intercept & Slope & $\mathrm{n}$ \\
\hline Boehringer & 0.98 & +0.17 & 0.96 & 50 \\
Behring & 0.996 & +0.65 & 0.9 & 15 \\
Merck & 0.99 & +3.2 & 0.9 & 15 \\
Sigma & 0.99 & +0.72 & 0.98 & 15 \\
\hline
\end{tabular}

\section{Discussion}

During the past few years the purity and stability of commercially available preparations of the NAD(P)H-linked bacterial luciferase system, including that of the substrates and cofactors has been considerably improved. In additión, automatic instruments especially designed for luminometry are being offered by several manufacturers. With respect to the quality of reagents and instrumentation, bioluminescent methods should now be easily applicable in routine clinical analysis. However, one difficulty in using luminescence assays in routine analysis in the clinical laboratory resides in the fact that none of the commercially available preparations of enzymes and coenzymes, which potentially can be coupled to luminescence, has been especially tested for impurities, which may cause either high blank readings, or interfere with light production during luminescent measurements.

Preparations of NAD, for instance, often contain large amounts of AMP which might interfere in assays coupled to the firefly luciferase system (1). We have recently published methods for the determina: tion of glycerol and free fatty acids $(2,3,4)$. Due to unknown impurities of enzymes and coenzymes the $\mathrm{NADH}$ formed had to be diluted in order to reduce blank readings and to obtain a sufficiently wide dynamic range. This dilution step precluded automatic measurements. Similar problems might occur on coupling other dehydrogenase reactions to the bacterial $\mathrm{NAD}(\mathrm{P}) \mathrm{H}$-linked luciferase system. In order to test this latter possibility, we have coupled reagent kits originally designed for spectrophotometric measurements of glucose in serum samples (Boehringer, Behring, Merck, Sigma) to the bacterial luciferase system. We thereby showed that the different commercially available reagent kits for glucose determination are sufficiently pure to allow the fully automatic bioluminescent determination of glucose. The Boehringer Gluco-quant kit shows a favourable signal to noise ratio as well as a wide dynamic range. We were therefore able to couple the reagent kit to the bioluminescent system without further dilution. of the NADPH formed. The principle of coupling conventional reagent kits to a bioluminescent method is also applicable to other commercially available preparations for spectrophotometric glucose determinations (Behring, Merck, Sigma). Due to their low blank readings and their favourable dynamic range $(2-100$ $\mu \mathrm{mol} / \mathrm{l})$ the Behring and the Merck kits can also be fully automated in the same way as the Boehringer kit. The Sigma kit, however, was less suitable for automation with respect to its detection limit and dynamic range $(4-30 \mu \mathrm{mol} / \mathrm{l}) \cdot \cdot \mathrm{r}$ 
Using the bioluminescent approach, the reagent kits are at least 100 times more sensitive than spectrophotometric methods. Precision and accuracy of the method meet the demands for routine analysis in clinical chemistry. Due to the relatively high dilution (100-150-fold) of native samples, treatment with the fluoride, usually performed to inhibit glycolysis, did not interfere with the bioluminescent signal. For the same reason, the samples were not treated with acid to stop possible $\mathrm{NAD}(\mathrm{P}) \mathrm{H}$ degradation by interfering serum dehydrogenases, Using reagent kits for luminometry (LKB Wallac, Lumac/3 M, Boehringer Mannheim) and reagent kits for spectrophotometric glucose determination, the complete assay can be performed with commercially available reagents. A laboratory-internal assay cocktail was produced which reduced costs by approximately $90 \%$ when compared with commercially available luciferase reagent kits. A number of other highly sensitive methods for the luminescent determination of glucose have been published $(5-8)$. All these assays, either bioluminescent or chemiluminescent, are poorly applicable to routine analysis in the clinical laboratory. The bioluminescent method of Brolin et al. (5) was published at a time when only crude preparations of the bacterial $\mathrm{NAD}(\mathrm{P}) \mathrm{H}$-linked luciferase system were available. For that reason it has never been validated on a reliable number of actual samples. The method based on the immobilized bacterial luciferase system (6) has the disadvantage of not being available commercially, as well as requiring special equipment. The chemiluminescent methods $(7,8)$ based on glucose oxidation and $\mathrm{H}_{2} \mathrm{O}_{2}$ formation cannot be applied to untreated biological samples.

The method presented here offers considerable advantages for the clinical laboratory. Because of its high sensivity only a few microliters of a sample are needed for each determination. In addition, it is automatic and completely based on commercially available reagents and test combinations.

In summary, this report shows that in contrast to luminescent immunoassays (LIA), which are not yet available as kits ready for use, the bioluminescent measurement of substrates is already suitable for routine application in clinical chemistry. By coupling conventional reagent kits to the bacterial luciferase system, bioluminescence is a reliable and highly sensitive tool for the determination of a wide range of serum components, provided that the reagents are selected which give an optimal dynamic range (signal to noise ratio).

\section{References}

1. Campbell, A. K. \& Simpson, J. S. A. (1971) Chemi- and bioluminescence as an analytical tool in biology. In: Techniques in the life sciences, Biochemistry - Volume B2/II, Techniques in metabolic research - Part II. (Kornberg, H. I., Metcalfe, J. C., Northcote, D. H., Pogson, C. I. \& Tipton, K. F., eds.) Elsevier/North Holland Scientific Publisher Ltd., pp. $1-56$.

2. Kather, H. \& Wieland, E. (1984) Anal. Biochem. 140, $349-353$.

3. Kather, H. \& Wieland, E. (1984) Glycerol, luminometric method. In: Methods of Enzymatic Analysis (Bergmeyer, H. U., ed.) Verlag Chemie, Weinheim, Vol. VI, pp. 510-518.

4. Wieland, E., Fischer, B. \& Kather, H. (1985) J. Clin. Chem. Clin. Biochem. 23, 99-103.

5. Brolin, S. E., Borlund, E., Tegner, L. \& Wettermark, G. (1971) Anal. Biochem. 42, 124-135.

6. Jablonski, E. \& Deluca, M. (1978) Meth. Enzymol. 57, $202-214$.

7. Auses, J. P., Cook, S. L. \& Maloy, S. T. (1970) Anal. Chem. 47, 244-249.

8. Bostick, D. T. \& Hercules, D. M. (1974) Anal. Lett. 7, $347-353$.

Dr. Eberhard Wieland

Klinisches Institut für

Herzinfarktforschung an der

Universitätsklinik Heidelberg

Bergheimerstr. 58

D-6900 Heidelberg 
$\therefore$ 